\title{
PENGARUH METODE PSIKOEDUKASI TERHADAP PERILAKU SEKSUAL PRANIKAH PADA REMAJA PUTRI
}

\author{
Wanodya Kusumastuti \\ Fakultas IImu Sosial Program Studi Psikologi \\ Universitas Muhammadiyah Purworejo \\ wanodyakusumastuti@gmail.com
}

\begin{abstract}
The aims of this study to see the influence of psychoeducation of Islamic sex and reproductive health to reduce premarital sexual behavior in young women. Premarital sexual behavior is an indicator of the behavior of dating, kissing and exploring the genital area. Research subjects are students whose dating style leads to indicators of premarital sexual behavior. Data collection techniques used interview methods and the scale of premarital sexual behavior. Data analysis using ANOVA test to find out the influence of psychoeducation toward the change of premarital sexual behavior and different test to know the magnitude of psychoeducation effect on the change of premarital sexual behavior. ANOVA test results showed that both psychoeducation was incapable of changing premarital sexual behavior. However, different tests show that Islamic sex psycho-education is more effective at lowering one of the premarital sexual behavior indicators of kissing behavior than reproductive health psychotherapy. Based on the results of the study, it can be concluded that Islamic sex psychoeducation is more effective in reducing the indicator of kissing behavior in female students.
\end{abstract}

Keywords: psychoeducation, sex, Islami

Abstrak. Penelitian ini bertujuan melihat pengaruh psikoedukasi seks Islami dan kesehatan reproduksi untuk menurunkan perilaku seksual pranikah pada remaja putri. Perilaku seksual pranikah adalah indikator perilaku berkencan, berciuman dan eksplorasi daerah genital. Subjek penelitian adalah siswi yang gaya berpacarannya mengarah pada indikator perilaku seksual pranikah. Teknik pengumpulan data menggunakan metode wawancara dan skala perilaku seksual pranikah. Analisis data menggunakan uji ANOVA untuk mengetahui pengaruh psikoedukasi terhadap perubahan perilaku seksual pranikah serta uji beda untuk mengetahui besarnya pengaruh psikoedukasi terhadap perubahan perilaku seksual pranikah. Hasil analisis uji ANOVA menunjukkan kedua psikoedukasi tidak mampu mengubah perilaku seksual pranikah. Namun, berdasarkan uji beda menunjukkan bahwa psikoedukasi seks Islami lebih efektif menurunkan salah satu indikator perilaku seksual pranikah yaitu perilaku berciuman daripada psikoedukasi kesehatan reproduksi. Berdasarkan hasil penelitian, dapat disimpulkan bahwa psikoedukasi seks Islami lebih efektif menurunkan indikator perilaku berciuman pada siswi.

Kata kunci: psikoedukasi, seks, Islami

\section{PENDAHULUAN}

Masa remaja adalah saat dimana mulai timbul ketertarikan pada proses pencarian identitas diri dan mengalami proses perkembangan seksual yang cepat. Masa remaja juga merupakan masa yang dipenuhi oleh konflik dan suasana perubahan suasana hati (Santrock, 2002). Pada masa ini, Kemasakan seksual berpengaruh terhadap timbulnya perubahan sikap dan perilaku sosial remaja yang ditunjukkan dengan beralihnya perhatian remaja ke lawan jenis, kemudian diikuti perasaan saling tertarik, saling mendekati dan keinginan untuk mengadakan kontak fisik yang disertai nafsu seksual (Monks, 1999). Menurut Hurlock (1999) hanya sedikit remaja yang mendapatkan informasi 
mengenai seksualitas dari orang tua. Oleh karena itu, remaja mencari sumber informasi yang mungkin diperoleh, misalnya dari sekolah, membahas dengan teman sebaya, membaca buku tentang seks, mencoba melakukan masturbasi, bercumbu dan bersenggama.

Tingginya minat tentang seksualitas menimbulkan dorongan seksual pada remaja yang tidak terkontrol. Kondisi tersebut membuat remaja cenderung menunjukkan perilaku seperti pacaran hingga melakukan seks pranikah dan kumpul kebo (Dariyo, 2004). Hasil pengambilan data di SMP $Y$ melalui metode survey dan wawancara menunjukkan bahwa remaja yang berpacaran memiliki minat seksualitas di usianya yang masih muda. Hasil tersebut menunjukkan siswi yang berusia 14 tahun sebanyak 17 orang sudah berciuman (kissing) saat pacaran, siswi berusia 14 tahun yang sudah mencium leher pacar (necking) hingga menimbulkan rangsangan dan memegang payudara pacar ada sepuluh orang dan siswi yang menggesek-gesekkan alat kelamin (petting) ada lima orang. Ada tiga orang siswi yang berusia 15 tahun sudah melakukan hubungan seksual dengan pacar. Kondisi tersebut menunjukkan bahwa siswi dengan usia yang relatif masih muda sudah memiliki pengalaman seksual yang melampaui batas.

Tingginya resiko pergaulan bebas yang mengarah pada perilaku seksual pranikah, menyebabkan kehamilan yang tidak diinginkan (KTD) pada remaja putri dan menimbulkan resiko jangka panjang. Kondisi tersebut terjadi pada siswi SMP Y yaitu ada tiga siswi yang pacaran dan sudah melakukan hubungan seksual hingga hamil dan aborsi. Menurut Notoatmodjo (2007) minimnya pengetahuan terhadap kesehatan reproduksi membuat remaja tidak mengetahui akibat perilaku seksual pranikah. Beberapa dampak perilaku seksual pranikah remaja terhadap kesehatan reproduksi, yaitu: 1) kehamilan yang tidak dikehendaki (KTD), 2) penyakit menular seksual (HIV/AIDS atau penyakit menular seksual), 3) dampak psikologis yang menyebabkan kehamilan akan memuncukan perasaan bingung, cemas, malu dan perasaan bersalah yang bercampur dengan depresi, rasa pesimis terhadap masa depan, perasaan marah baik pada diri sendiri maupun pasangan.

Besarnya resiko yang harus ditanggung oleh perempuan akibat aborsi menjadi sesuatu hal yang harus diperhatikan, sehingga remaja perlu memiliki pengetahuan supaya remaja putri dapat menjaga diri dari pergaulan bebas. Pengetahuan diperlukan karena remaja putri rentan mengalami kehamilan di luar pernikahan dan aborsi. Dalam norma kesusilaan, perilaku seksual pranikah merupakan perilaku yang melanggar norma sosial. Agama juga melarang keras seseorang melakukan perilaku di luar koridor agama. Beberapa ayat Al-Qur'an membahas mengenai pentingnya mengendalikan dorongan seksual sehingga terbentuk etika pergaulan Islami yaitu:

'Dan janganlah kamu mendekati zina. Sesungguhnya zina itu adalah suatu perbuatan yang keji dan suatu jalan yang buruk' (Q.S Al-Isra': 32).

Penjelasan dari Q.S Al-Isra': 32 yaitu Allah SWT melarang perzinaan karena perzinaan merupakan pembunuhan dalam berbagai segi. Pertama penempatan sperma bukan pada tempatnya yang sah. Kondisi ini menimbulkan keinginan untuk menggugurkan, yaitu membunuh bayi yang dikandung. Apabila janin yang dilahirkan hidup, maka ia akan dibiarkan begitu saja tanpa ada yang memelihara dan mendidiknya. Di sisi lain, perzinaan juga membunuh masyarakat untuk 
memudahkan manusia melampiaskan nafsu. Perzinaan terjadi karena adanya dorongan seksual yang tidak dapat dikendalikan.

Qudsy (2012) menjelaskan bahwa dorongan seksual berawal dari pandangan mata. Pandangan adalah pintu awal seseorang melihat objek lain. Pandangan terhadap lawan jenis tanpa tujuan syar'i diharamkan karena hal itu dapat menjerumuskan seseorang pada kemaksiatan, sehingga akan menimbulkan khayalankhayalan yang tidak baik dalam pikiran seseorang dan dapat merusak hatinya. Apabila seseorang telah terbiasa menundukkan pandangannya dengan rasa takut kepada Allah SWT, maka akan melahirkan kemantapan iman dalam hati dan terjaga dari tipu daya setan (Qudsy, 2012). Menurut Behle (Ekawati, 2008) perilaku seks yang dilakukan sebelum menikah oleh remaja putri akan mengakibatkan resiko antara lain kehamilan, kelahiran prematur dan kelainan pada bayi. Secara sosial, remaja putri yang melahirkan memiliki konsekuensi berhenti dan dikeluarkan dari sekolah, tidak mudah mendapatkan pekerjaan, dan diasingkan oleh kelompok sebaya bahkan sosial masyarakat. Secara psikologis, remaja putri yang hamil sebelum menikah akan merasa malu, dan kotor apalagi jika dikaitkan dengan fungsinya setelah melahirkan yaitu menjadi orang tua yang terlalu muda.

Penelitian dari Sudan, Hisham, Rahman \& Abdallah (2012) mengenai tindakan pencegahan perilaku seksual pranikah pada remaja: model agama Islam. Metode yang diberikan dengan memahami materi seksualitas berdasarkan ayat Al-Qur'an dan hadits. Penelitian ini menjelaskan bahwa agama memainkan peran penting dalam kegiatan seksual remaja. Selain itu, penelitian ini menunjukkan peran agama dikaitkan dengan abstinance (penundaan) perilaku seksual pranikah di kalangan remaja.

Santrock (2002) menjelaskan masa remaja merupakan waktu untuk bereksplorasi dan bereksperimen terkait masalah seksualitas, fantasi dan realita seksual. Oleh karena itu, dorongan seksual remaja ini sangat tinggi dan bahkan lebih tinggi dari dorongan seksual orang dewasa. Remaja mencoba untuk melepaskan ketegangan seksual dengan mengekpresikan dorongan seksualnya dalam berbagai bentuk tingkah laku seksual, mulai dari aktivitas berpacaran dating), berkencan, bercumbu dampai melakukan kontak seksual (Santrock, 2002). Hal tersebut juga diperkuat dengan pendapat dari Nanggala (Naedi, 2012) bahwa perilaku seksual pranikah merupakan pola perilaku seks yang bebas dan tanpa batasan, baik dalam tingkah laku seksnya maupun dengan siapa seks itu dilakukan. Lebih lanjut dijelaskan bahwa perilaku seksual pranikah dilatarbelakangi oleh beberapa hal yaitu: 1) kurangnya pemahaman nilai-nilai agama, 2) belum adanya pendidikan seks secara formal di sekolah, 3) pengaruh teman, internet, dan lingkungan, 4) penyebaran gambar dan VCD porno melalui berbagai media, 5) penggunaan NAPZA.

Berdasarkan penjelasan tersebut menunjukkan bahwa perilaku seksual pranikah dekat dengan kehidupan remaja, apalagi remaja yang sudah berpacaran, mudah mendapatkan akses informasi negatif, kurangnya wawasan keagamaan, terlibat dalam pergaulan bebas dan kurang mendapat pengawasan dari orang tua (Ritandiyono \& Andisti, 2008). Oleh karena itu, remaja harus mendapatkan informasi yang tepat untuk menjaga diri supaya tidak terjerumus pada pergaulan bebas dan perilaku seksual pranikah. Informasi mendasar yang harus dimiliki remaja adalah pengetahuan yang 
berkaitan dengan kesehatan reproduksi dan pendidikan agama Islam dalam memandang perilaku seks pranikah. Informasi yang bertujuan untuk memberikan pengetahuan ini dalam bentuk psikoedukasi. Dalam kode etik psikologi (2010) psikoedukasi merupakan kegiatan yang dilakukan untuk meningkatkan pemahaman dan atau keterampilan sebagai usaha pencegahan dari munculnya dan atau meluasnya gangguan psikologis di suatu kelompok, komunitas dan masyarakat.

Psikoedukasi yang akan dilakukan dalam penelitian ini adalah psikoedukasi kesehatan reproduksi yaitu pendidikan seks yang mengkaji seksualitas manusia bukan sekedar kajian pelajaran biologi atau ilmu sosial. Tujuan pendidikan seks adalah mendorong ketrampilan atau kecakapan, sikap, kecenderungan, perlaku dan refleksi kritis terhadap pengalaman pribadi Reiss \& Halstead, 2006). Forrester (Makol-Abduh, dkk 2009) menjelaskan bahwa remaja memiliki hak untuk mendapatkan pendidikan seks, materi tersebut sebagai sarana untuk melindungi diri terhadap penyalahgunaan, eksploitasi, kehamilan yang tidak diinginkan, penyakit menular seksual dan HIV/AIDS. Program pendidikan seks sudah menjadi program gerakan internasional yang bertugas mendukung hak remaja untuk mendapatkan informasi yang akurat dan relevan tentang seksualitas, sehingga dapat membantu remaja membuat keputusan dari perilaku seksual mereka (Kirby, 2011). Tujuan kesehatan reproduksi remaja (Wahyudi, 2000) yaitu 1) menurunkan resiko kehamilan dan pengguguran yang tidak dikehendaki, 2) menurunkan resiko IMS/HIV-AIDS, 3) informasi mengenai organ reproduksi dan proses reproduksi serta pentingnya menjaga organ reproduksi dengan baik.
Selain psikoedukasi kesehatan reproduksi, psikoedukasi yang dapat diberikan pada siswi yaitu psikoedukasi seks Islami yaitu upaya menumbuhkembangkan kemampuan melalui pengajaran yang berkaitan dengan pendidikan seks sesuai ajaran Islam (Sudan, Hisham, Rahman \& Abdallah, 2012). Islam menurunkan ayat-ayat yang mengatur cara berperilaku untuk kesejahteraan umat manusia, kesehatan fisik, melindungi keturunan dan menjaga nama baik keluarga (Sudan, dkk, 2012). Salah satu fitrah manusia adalah fitrah berupa dorongan seksual. Maka agar dorongan dapat berjalan sesuai dengan yang dikehendaki oleh Allah SWT, Islam perlu memberikan pembinaan baik perintah maupun larangan (Hafidz, 1997). Rasulullah SAW. menyuruh menutup aurat agar tidak dilihat orang lain. Hal ini karena aurat merupakan bagian tubuh yang harus dijaga dari pandangan orang (Hafidz, 1997). Anak yang mencapai aqil baligh akan memahami persoalan hidup termasuk tahu bagaimana bergaul dengan lawan jenis. Menurut Ulwan (1996) perlu adanya upaya pengajaran, penyadaran dan penerangan tentang masalahmasalah seksual yang diberikan kepada anak sejak mengerti masalah-masalah yang berkenaan dengan seks, naluri, dan perkawinan. Jadi ketika anak telah tumbuh dewasa, ia dapat mengetahui masalahmasalah yang diharamkan dan dihalalkan. Diharapkan anak mampu menerapkan perilaku Islami.

Pengajaran yang diberikan pada remaja untuk menerapkan perilaku Islami yaitu psikoedukasi seks Islami. Menurut Qudsy (2012) tujuan yang ingin dicapai dalam memberikan psikoedukasi kepada anak berdasarkan pendidikan seks menurut ajaran Islam adalah 1) penanaman dan pengukuhan akhlak sejak dini kepada anak dan remaja dalam menghadapi masalah seksual agar tidak 
mudah terjerumus pada pergaulan bebas, 2) remaja mengetahui secara benar tentang seksualitas dan akibat-akibatnya jika dilakukan tanpa mematuhi aturan syar'i, 3) remaja mengetahui aturan yang syar'i berhubungan dengan seks sehingga mampu menjaga kehormatan diri, 4) upaya preventif dalam kerangka moralitas agama untuk menghindarkan remaja dari pergaulan bebas dan penyimpangan seksual, 5) membentuk sikap emosional yang sehat terhadap masalah seksual dan membimbing remaja ke arah hidup dewasa yang bertanggung jawab terhadap kehidupan seksualnya.

Pendidikan ajaran Islam yang secara spesifik membahas mengenai pendekatan religius sebagai upaya pencegahan perilaku seksual pranikah pada remaja (Sudan, Hisham, Rahman \& Abdallah, 2012) menjelaskan beberapa hal, antara lain: 1) akhlaq sebagai mekanisme penting dalam mengontrol perilaku seksual pranikah remaja. Rasulullah SAW. dalam hadist mengingatkan bahwa perannya sebagai seorang nabi terutama untuk mencegah kesalahan termasuk seks pranikah melalui ajaran agama, 2) model peran baik, di dalam Islam, ayah adalah pemimpin keluarga dan ibu adalah sumber cinta seluruh anggota keluarga. Anak-anak remaja membutuhkan cinta dan kasih sayang dari orang tua yang positif sehingga akan mendorong pencegahan kegiatan terlarang, 3) Islam mengajarkan untuk mengenakan pakaian yang sopan dan menutup aurat. Tujuannya untuk menjaga kesucian dan kesopanan, 4) menjaga pandangan untuk menghindari godaan seksual, 5) larangan berkhalwat (berduaan antara laki-laki dan perempuan tanpa ada hubungan mahram).

Dapat disimpulkan bahwa faktorfaktor pencegahan dalam pandangan ajaran Islam dimulai dari perbaikan akhlaq yang diikuti oleh perubahan perilaku. Hal tersebut berbeda dengan psikoedukasi kesehatan reproduksi yang menitikberatkan pada pengetahuan fisiologis. Berdasarkan uraian di atas perlu dikaji lebih lanjut mengenai perbedaan efektifitas antara psikoedukasi kesehatan reproduksi dan psikoedukasi seks Islami terhadap perilaku seksual pranikah remaja putri di SMP Y.

\section{METODE PENELITIAN}

Variabel bebas dalam penelitian ini adalah psikoedukasi kesehatan reproduksi dan psikoedukasi seks Islami. Variabel tergantung dalam penelitian ini adalah perilaku seks pranikah. Intervensi berupa psikoedukasi mengacu pada prinsip prevention dan promotion. Konsep prevensi menurut Gerald Caplan (Dalton dalam Pranungsari, 2012) mengenai pencegahan kesehatan terdiri dari primary prevention yaitu pencegahan dini yang didasarkan pada kelompok individu yang belum mengalami suatu gejala gangguan tertentu. Secondary prevention yaitu tindakan yang dilakukan pada kelompok individu yang telah menunjukkan gejalagejala awal (early sympotms) yang mengindikasikan dan mengarah pada suatu gangguan tertentu sebagai bentukdari usaha pertolongan yang lebih awal untuk melakukan suatu pencegahan. Tertiary prevention merupakan intervensi yang diberikan kepada individu atau kelompok yang telah terkena suatu gangguan tertentu, agar gangguan tersebut berlangsung tidak terlalu lama. Intervensi yang dilakukan pada penelitian ini merupakan secondary prevention yaitu tindakan yang dilakukan pada komunitas siswi SMP $Y$ yang telah menunjukkan gejala-gejala awal perilaku pacaran mengarah pada aktivitas seksual pranikah.

Rancangan penelitian yang akan dilakukan menggunakan pendekatan action research (penelitian tindakan). Dalam penelitian tindakan, peneliti 
mendeskripsikan, menginterpretasikan dan menjelaskan suatu situasi sosial pada waktu yang bersamaan dengan melakukan perubahan atau intervensi dengan tujuan perbaikan dan partisipasi (Madya, 2006). Rencana tindakan dilakukan melalui tahap-tahap yaitu 1) asesmen permasalahan komunitas (entrance), 2) mendiagnosis permasalahan komunitas (diagnosis), 3) membuat rencana tindakan (action planning), melaksanakan intervensi (intervention), mengevaluasi hasil intervensi (evaluation), melakukan refleksi dengan mendengarkan masukan dari subjek, guru, dan pemberi materi (reflection). Pada tahap reflection, apabila hasil refleksi berhasil dilakukan maka tujuan dari penelitian sudah tercapai. Namun apabila hasil refleksi belum memenuhi tujuan penelitian, maka peneliti memperdalam diagnosis permasalahan lagi sehinga dapat menjadi bahan penelitian selanjutnya.

Partisipan peneltian ini adalah siswi SMP Y. Karakteristik partisipan dalam penelitian ini adalah sebagai berkut: 1) remaja putri beragama Islam, 2) berusia 12-15 tahun, 3) berpacaran dan melakukan aktivitas seksual (kissing, necking, petting, intercourse), 4) bersedia mengikuti keseluruhan proses intervensi.

Instrumen atau alat-alat dalam penelitian berupa skala perilaku seksual pranikah yang disusun berdasarkan bentuk-bentuk perilaku seksual pranikah yaitu berkencan, berciuman, eksplorasi daerah genital pasangan, dan bersenggama (Sarwono, 2007). Skala tersebut diujicobakan pada 42 remaja putri di SMP $Y$ dengan karakteristik subjek berpacaran dan menunjukkan aktivitas seksual pranikah. Hasil analisis item skala perilaku seksual pranikah menunjukkan bahwa sebanyak 25 item awal setelah dilakukan uji coba, diperoleh 20 item sahih dan 5 item gugur. Indikator perilaku yang selanjutnya digunakan sebagai item penelitian yaitu berkencan, berciuman dan eksplorasi daerah genital. Item bersenggama tidak digunakan karena item tidak sahih yang menunjukkan bahwa perilaku seksual pranikah siswi SMP $Y$ belum sampai fase bersenggama.

Dari 20 item yang sahih dilakukan uji statistik dengan konsistensi internal berkisar antara 0.21 sampai 0.82 dan reliabilitas alpha cronbach 0.94 . Instrumen lain yang digunakan dalam pengumpulan data adalah wawancara untuk memperoleh gambaran mengenai perilaku seksual pranikah yang dilakukan remaja saat berpacaran. Instrumen terakhir yang digunakan untuk mendukung penelitian ini adalah modul psikoedukasi kesehatan reproduksi yang terdiri dari 3 tahap antara lain tahap 1 meliputi 3 sesi (mengenal perilaku pacaran remaja, menstruasi, review materi pertemuan 1). Tahap 2 meliputi 5 sesi (pemeliharaan alat-alat reproduksi, kehamilan, aborsi, HIV/AIDS dan review materi pertemuan 2). Tahap 3 meliputi 5 sesi (abstinance, perilaku seksual remaja, perilaku seksual yang bertanggung jawab, review keseluruhan materi, serta post test dan evaluasi seluruh kegiatan). Psikoedukasi seks Islami yang terdiri dari 2 tahap antara lain tahap 1 meliputi 3 sesi (mengenal perilaku pacaran remaja, pokok-pokok psikoedukasi seks Islami 1, review materi pertemuan 1). Tahap 2 meliputi 3 sesi (pokok-pokok psikoedukasi seks Islami 2, review materi pertemuan 1 dan 2, serta post test dan evaluasi seluruh kegiatan).

Metode analisis data yang digunakan untuk melihat efektivitas psikoedukasi kesehatan reproduksi dan psikoedukasi seks Islami adalah one way ANOVA. Uji ANOVA dihitung untuk mengetahui skor total perilaku seksual setelah mendapat perlakuan (post test) dan follow up. Uji statistik juga menggunakan independent sample t-test 
untuk mengetahui perbedaan pengaruh psikoedukasi terhadap perilaku seksual pranikah. Independent sample t-test menganalisis hingga skor per aspek. Kedua uji statistik one way ANOVA dan independent sample t-test juga menghitung effect size yang bertujuan untuk mengetahui seberapa besar pengaruh psikoedukasi tersebut pada masing-masing aspek.

\section{HASIL DAN PEMBAHASAN}

Berdasarkan uji ANOVA yang dilakukan untuk mengetahui pengaruh psikoedukasi kesehatan reproduksi dan psikoedukasi seks Islami terhadap perilaku seksual pranikah.

Tabel 1.

Uji ANOVA dan effect size

\begin{tabular}{|c|c|c|c|c|}
\hline \multirow[t]{2}{*}{ Variabel Penelitian } & \multicolumn{3}{|c|}{ Uji ANOVA } & \multirow[t]{2}{*}{ Effect size } \\
\hline & df & Sig. & & \\
\hline $\begin{array}{l}\text { Perilaku seksual } \\
\text { pranikah (post test) }\end{array}$ & 1.645 & $2(21)$ & .217 & $9 \%$ (medium effect) \\
\hline Berkencan (post test) & 1.262 & $2(21)$ & .304 & $9 \%$ (medium effect) \\
\hline Berciuman (post test) & 2.377 & $2(21)$ & .117 & $4 \%$ (small effect) \\
\hline $\begin{array}{l}\text { Eksplorasi daerah } \\
\text { genital (post test) }\end{array}$ & 1.000 & $2(11)$ & .385 & $1 \%$ (small effect) \\
\hline $\begin{array}{l}\text { Perilaku seksual } \\
\text { pranikah (follow up) }\end{array}$ & .072 & $2(11)$ & .931 & $0 \%$ (small effect) \\
\hline Berkencan (follow up) & .362 & $2(11)$ & .701 & $4 \%$ (small effect) \\
\hline Berciuman (follow up) & .955 & $2(11)$ & .401 & $9 \%$ (medium effect) \\
\hline $\begin{array}{l}\text { Eksplorasi daerah } \\
\text { genital (follow up) }\end{array}$ & 1.000 & $2(11)$ & .385 & $9 \%$ (medium effect) \\
\hline
\end{tabular}

Cohen (Field, 2009) membuat kategori yang dapat digunakan untuk mengetahui dampak dari suatu perlakuan. Kategori effect size dapat diklasikan sebagai berikut:

$\mathrm{r}=.10$ (small effect): efek terhadap $1 \%$ dari total varian

$r=.30$ (medium effect): efek terhadap $9 \%$ dari total varian

$r=.50$ (large effect): efek terhadap $25 \%$ dari total varian.

Berdasarkan tabel tersebut dapat dilihat bahwa tidak ada pengaruh skor perilaku seksual pranikah setelah mendapat perlakuan (post test), skor ANOVA post test $\mathrm{p}=0.217$. Meskipun hasil tidak signifikan, namun kedua psikoedukasi memberikan efek yang cukup besar yaitu 9\% (medium effect). Pada skor tindak lanjut (follow up) terlihat skor kenaikan ANOVA yaitu $p=0.931$, namun pengaruhnya kecil. Dari skor per aspek menunjukkan tidak ada pengaruh yang signifikan antara skor post test dan skor follow up. Perilaku berkencan, skor post test $\mathrm{p}=0.304$ dan memberikan pengaruh yang cukup besar (medium effect) sebesar 9\%. Saat tindak lanjut (follow up), $\mathrm{p}=0.701$, namun pengaruhnya kecil yaitu 4\%. Pada perilaku berciuman, skor post test-nya $\mathrm{p}=0.117$ dan skor follow up $\mathrm{p}=0401$. Pada perilaku eksplorasi daerah genital, skor post test-nya $\mathrm{p}=0.385 \%$ dengan pengaruh yang sangat kecil dan setelah masa tindak lanjut skornya $0.385 \%$ dengan pengaruh yang cukup besar $=9 \%$.Selanjutnya uji hipotesis menggunakan independent sample t-test. 
Tabel 2.

Uji Hipotesis dan Effect size

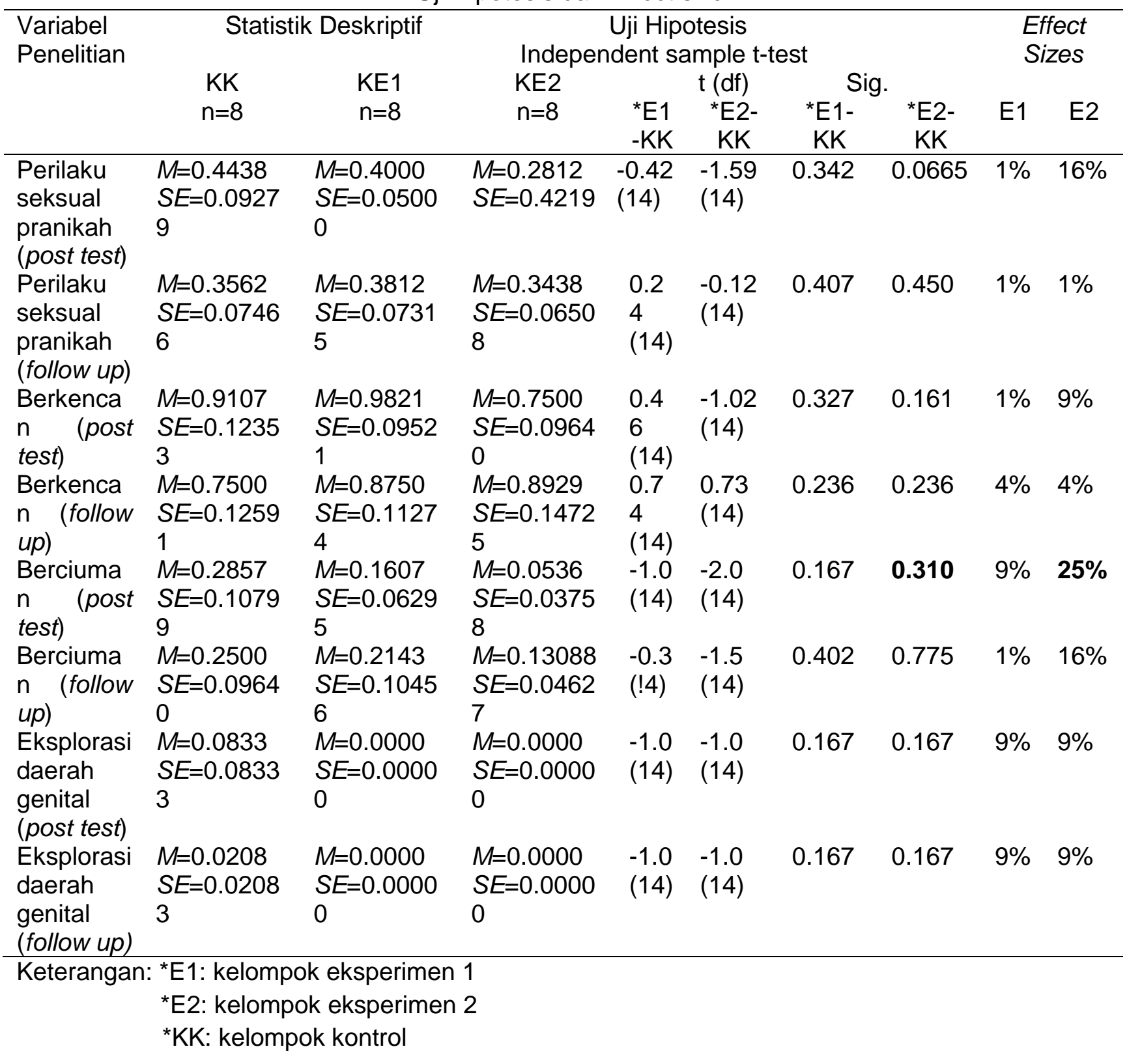

Berdasarkan tabel diatas dapat dijelaskan bahwa partisipan kelompok eksperimen 1 dan kelompok eksperimen 2 tidak mengalami perubahan perilaku seksual pranikah, baik setelah mendapat psikoedukasi atau setelah tindak lanjut. Meskipun hasil statistik tidak menunjukkan hasil yang signifikan, namun kedua psikoedukasi yang diberikan masih dapat dilihat sumbangan efektifnya. Dibawah ini dijelaskan perbandingan antara kelompok eksperimen dan kontrol.

1) Kelompok Eksperimen 1-Kelompok Kontrol

a. Partisipan kelompok eksperimen 1 yang mendapatkan psikoedukasi kesehatan reproduksi mengalami perubahan pada perilaku berciuman (post test) $(M=0.1607$, $S E=0.06295$ ) dibandingkan dengan perilaku berciuman pada kelompok 
kontrol $(M=0.2857, \quad S E=0.10799)$

dan psikoedukasi tersebut memberikan sumbangan efektif $9 \%$ (medium effect size)

b. Partisipan kelompok eksperimen 1 yang mendapatkan psikoedukasi kesehatan reproduksi mengalami perubahan pada perilaku eksplorasi daerah genital (post test) $\quad(M=0.0833, \quad S E=0.08333)$ dibandingkan perilaku eksplorasi daerah genital pada kelompok kontrol $(M=0.0000, \quad S E=0.00000)$ dan psikoedukasi tersebut memberikan sumbangan efektif $9 \%$ (medium effect size).

c. Partisipan kelompok eksperimen 1 yang mendapatkan psikoedukasi kesehatan reproduksi mengalami perubahan pada perilaku eksplorasi daerah genital (follow up) $(M=0.0000, S E=0.00000)$ dan psikoedukasi tersebut memberikan sumbangan efektif 9\% (medium effect size).

2) Kelompok Eksperimen 2-Kelompok Kontrol

a. Partisipan pada kelompok eksperimen 2 yang mendapatkan psikoedukasi seks Islami mengalami perubahan pada perilaku seksual pranikah (post test) $(M=0.2812, \quad S E=0.4129)$ dibandingkan perilaku seksual pranikah oada kelompok kontrol $\quad(M=0.04438$, $S E=0.09279$ ) dan psikoedukasi yang disusun memberikan sumbangan efektif $16 \%$ (medium effect size).

b. Partisipan pada kelompok eksperimen 2 yang mendapatkan psikoedukasi seks Islami mengalami perubahan pada perilaku berkencan (post test)
$(M=0.9107, \quad S E=0.12353)$ dan psikoedukasi tersebut memberikan sumbangan efektif 9\% (medium effect size).

c. Partisipan pada kelompok eksperimen 2 yang mendapatkan psikoedukasi seks Islami mengalami perubahan pada perilaku berciuman (post test) $(M=0.0536, \quad S E=0.03758)$ dibandingkan perilaku berciuman pada kelompok kontrol $\quad(M=0.2857$, $S E=0.10799$ ) dan psikoedukasi tersebut memberikan sumbangan efektif $25 \%$ (large effect size)

d. Partisipan pada kelompok eksperimen 2 yang mendapatkan pendidikan seks Islami mengalami perubahan pada perilaku eksplorasi daerah genital (post test) $(M=0.0833, \quad S E=0.08333)$ dibandingkan perilaku eksplorasi daerah genital pada kelompok kontrol $(M=0.0000$, $S E=0.00000$ ) dan psikoedukasi tersebut memberikan sumbangan efektif $9 \%$ (medium effect size).

e. Partisipan pada kelompok eksperimen 2 yang mendapatkan psikoedukasi seks Islami mengalami perubahan pada perilaku eksplorasi daerah genital (follow up) $\quad(M=0.0208$, $S E=0.02083$ ) dibandingkan perilaku eksplorasi daserah genital pada kelompok kontrol $(M=0.0000, S E=0.00000)$ dan psikoedukasi tersebut memberikan sumbangan efektif 9\% (medium effect size). 
Keberhasilan intervensi yang dicapai dalam menurunkan perilaku seksual pranikah pada dipengaruhi oleh beberapa faktor, antara lain:1) asesmen, sebelum dilakukan pengambilan data, peneliti membangun kedekatan (building raport) dengan siswi supaya mereka mau mengungkapkan perasaan, pikiran dan perilaku pacaran yang mengarah pada aktivitas seksual. Building raport sudah dilakukan satu tahun sebelum penelitian dilakukan; 2) partisipan yang terlibat dalam intervensi ini terlibat secara aktif yaitu mengikuti setiap sesi psikoedukasi. Selain itu, adanya rasa kepercayaan partisipan terhadap peneliti membuat partisipan bersedia menceritakan masalahnya sehingga peneliti mendapatkan informasi yang dibutuhkan; 3) modul yang dibuat berdasarkan kebutuhan partisipan dan divisualisasikan dengan tampilan yang menarik untuk remaja; 4) fasilitator merupakan salah satu faktor keberhasilan psikoedukasi karena fasilitator mampu menyampaikan materi diselingi dengan menceritakan pengalamannya maupun pengalaman orang lain.

Kelemahan penelitian ini adalah peneliti tidak melakukan koordinasi dengan guru dan orang tua untuk melakukan pendampingan khusus pada siswi yang memiliki kecenderungan melakukan aktivitas seksual pranikah saat pacaran. Kondisi inilah yang membuat siswi kembali melakukan aktivitas pacaran. Beberapa penelitian terdahulu yang terkait dengan psikoedukasi diantaranya penelitian dari Fadhilah (2001) mengenai efektivitas psikoedukasi berbasis kognitif perilakuan untuk meningkatkan asertivitas terhadap perilaku seksual pranikah pada remaja perempuan. Penelitian tersebut bertujuan untuk memberikan psikoedukasi supaya remaja perempuan mampu berpikir dan berperilaku dengan tepat ketika ada ajakan untuk melakukan hubungan seksual pranikah.

Penelitian selanjutnya oleh Pranungsari (2012) yang berjudul psikoedukasi pacaran sehat untuk menurunkan resiko kekerasan seksual pada remaja perempuan komunitas anak jalanan. Hasil penelitian menunjukkan bahwa psikoedukasi cukup membantu remaja perempuan komunitas anak jalanan menerapkan gaya pacaran sehat supaya terhindar dari resiko kekerasan seksual.

\section{SIMPULAN}

Kesimpulan dari hasil penelitian ini bahwa psikoedukasi kesehatan reproduksi dan psikoedukasi seks Islami tidak memberikan pengaruh untuk mengubah perilaku seksual pranikah pada siswi SMP Y. Namun, psikoedukasi seks Islami lebih efektif daripada psikoedukasi kesehatan reproduksi untuk mengubah perilaku berciuman setelah mendapat intervensi (post test), namun belum mampu mengubah perilaku seksual pranikah secara keseluruhan. Intervensi yang diberikan masih sebatas memberikan informasi dan pengetahuan pada siswisiswi SMP Y. Oleh karena itu, terjadi peningkatan perilaku seksual pranikah pada tindak lanjut (follow up). Kondisi ini juga disebabkan karena partisipan belum mampu menolak ajakan pacar seperti berpegangan tangan, berduaan di kelas dan berpelukan. Maka dari itu perlu adanya intervensi lanjutan sehingga peserta berani menolak dan mengutarakan keinginannya pada pacar sehingga terhindar dari resiko perilaku seksual pranikah. 


\section{DAFTAR PUSTAKA}

Dariyo, A. (2004). Psikologi perkembangan remaja. Bogor: Ghalia Indonesia.

Ekawati, D.R. (2008). Pelatihan asertivitas pada remaja awal putri untuk meningkatkan perilaku asertif terhadap hubungan seks pranikah. Tesis (Tidak Diterbitkan). Yogyakarta: Universitas Gadjah Mada.

fadhillah. (2001). Psikoedukasi berbasis kognitif-keperilakuan untuk meningkatkan asertivitas terhadap perilaku seksual pranikah pada remaja putri di kota P. Tesis (Tidak DIterbitkan). Yogyakarta: Universitas Islam Indonesia

Hafidz, N. (1997). Manhaj tarbiyah al nabawwiyah li al-thifl (Mendidik Anak Bersama Rasulullah SAW) (Penerj: Kuswandini, dkk). Bandung: Al Bayan.

Hurlock, E.B. (1999). Psikologi perkembangan: Suatu pendekatan sepanjang rentang kehidupan (edisi ke-5). Jakarta: Erlangga.

Kirby, D. (2011). Sex education: Access and impact on sexual behavior of young people. New York: United Nations Expert Group Meeting on Adolescents, Youth and Development.

Madya, S. (2006). Teori dan praktik penelitian tindakan (action research). Bandung: Alfabeta.

Makol-Abduh, et., all. (2009). Parent's attitudes toward inclusion of sexuality education in malaysian school. international journal about parents in education. 3 (1), 42-56. Malaysia: international Islamic University Kuala Lumpur.

Monks, F.J., Knoers, A.M.P., \& Haditono, S.R. (1999). Psikoedukasi perkembangan: Pengantar dalam berbagai bagiannya. Yogyakarta: Gadjah Mada University Press.

Naedi, (2012). Gambaran tingkat pengetahuan seks bebas pada remaja kelas XI di SMAN 1 Cilengsi Kabupaten Bogor. Skripsi (Tidak Diterbitkan).

Notoatmodjo, S. (2007). Promosi kesehatan dan ilmu perilaku. Jakarta: Rineka Cipta.

Pranungsari, D. (2012). Psikoedukasi pacaran sehat untuk menurunkan resiko kekerasan seksual pada remaja perempuan komunitas anak jalanan. Tesis. Yogyakarta: UAD.

Reiss, M. \& Halstead, J.M. (2006). Pendidikan seks bagi remaja (terjemahkan oleh M. Taufiekurakhman). Yogyakarta: Alenia Press.

Ritandiyono \& Andisti, M.A. (2008). Religiusitas dan seks bebas pada remaja awal. Jurnal Psikologi. 3(2)

Santrock, J.W. (2002). Life-span development: perkembangan masa hidup (jilid 2). Jakarta: Erlangga.

Sarwono, W.S. (2007). Psikologi remaja. Jakarta: PT Raja Grafindo Persada.

Sudan, et., all. (2012). Islamic preventive measures on premarital teen sex: $A$ religious model. academic reseach international. 3 (2), 1-17 
Ulwan, A.N. (1996). Pendidikan seks. Bandung: Rosdakarya.

Qudsy, H.E. (2012). Ketika anak bertanya tentang seks (Panduan Islami Bagi Orang Tua Mendampingi Anak Tumbuh Menjadi Dewasa). Solo: Tiga Serangkai.

Wahyudi. (2000). Modul kesehatan reproduksi remaja. Yogyakarta: PKBI. 